\title{
GMR
}

\section{Description of the pre-reductional sex chromosome during male meiosis of Pachylis laticornis (Heteroptera: Coreidae)}

\author{
C.A. Banho ${ }^{1}$, K.C.C. Alevi ${ }^{2}$, L.L.V. Pereira ${ }^{1}$, T.S. Souza-Firmino ${ }^{1}$ and \\ M.M. Itoyama ${ }^{1}$ \\ ${ }^{1}$ Departamento de Biologia, Laboratório de Citogenética e Molecular de Insetos, \\ Instituto de Biociências, Letras e Ciências Exatas, Universidade Estadual Paulista, \\ Campus São José do Rio Preto, São José do Rio Preto, SP, Brasil \\ ${ }^{2}$ Laboratório Biologia Celular, Departamento de Biologia, \\ Instituto de Biociências, Letras e Ciências Exatas, Universidade Estadual Paulista, \\ Campus São José do Rio Preto, São José do Rio Preto, SP, Brasil \\ Corresponding author: C.A. Banho \\ E-mail: ce_artico@hotmail.com
}

Genet. Mol. Res. 15 (2): gmr.15027592

Received September 4, 2015

Accepted January 8, 2016

Published April 27, 2016

DOI http://dx.doi.org/10.4238/gmr.15027592

ABSTRACT. In Heteroptera, the division of sex chromosomes is well
defined as post-reductional for most of species, i.e., the first meiotic
division is equational and the second is reductional. However, in some
species pre-reductional division has been observed, whereby the first
meiotic divisionis reductional and the second is equational. These include
Anisops fieberi (Notonectidae), Ectrychotes disparate (Reduviidae),
Dictyonota tricornis (Tingidae), and Archimerus alternatus (Coreidae),
as well as other species of the genus Pachylis, in the family Coreidae.
Thus, this study aimed to characterize the meiotic behavior of Pachylis
laticornis, in order to consider whether this species also undergoes pre-
reduction division for the sex chromosomes. Cytogenetic analysis of
meiosis in P. laticornis made it possible to characterize the holocentric
nature of the chromosomes, the chromosome number of this species [2n 
$=15(2 \mathrm{~m}+12 \mathrm{~A}+\mathrm{X} 0)]$, the chromosomal system of sex X0 type, and the presence of $\mathrm{m}$-chromosomes. Furthermore, the analysis of anaphase I, telophase I and II allowed pre-reductional meiotic behavior to be observed for this sex chromosome. Thus, this meiotic behavior was confirmed for another species of Heteroptera, stressing the importance of more cytogenetic studies of meiosis to increase our understanding of variation in the behavior of sex chromosomes during spermatogenesis in heteropterans. Therefore, the present study describes the chromosomal number, the system of sex determination, and meiotic behavior of $P$. laticornis, corroborating the relationship of this species with others of the same genus.

Key words: Cytogenetics; Holocentric chromosomes; Coreoidea

\section{INTRODUCTION}

The suborder Heteroptera comprises the largest and most diverse group of insects that undergo hemimetabolous development. It consists of seven infraorders (Leptopodomorpha, Gerromorpha, Nepomorpha, Pentatomomorpha, Cimicomorpha, Dipsocoromorpha, and Enicocephalomorpha), with approximately 80 families (Schuh and Slater, 1995) and more than 40,000 species that have been described (Weirauch and Schuh, 2011).

Insects in this suborder have holocentric chromosomes and undergo post-reductional meiosis, which is restricted to the sex chromosomes and presents great diversity in the karyotype, ranging from $2 n=4$ to $2 n=80$ (Ueshima, 1979). In addition, micro-chromosomes have also been reported for many heteropteran species (Ueshima, 1979).

Members of the family Coreidae (Coreoidea, Pentatomomorpha, and Heteroptera) are known as leaf-footed bugs, and represent the family containing the largest number of species within the group, with approximately 2000 species distributed in 252 genres. They are cosmopolitan, however, being more concentrated in tropical regions. In the literature, $\sim 82$ of these species have been suggested to be potentially harmful to crops, and therefore, are of great economic importance. Among the crops that these insects can attack are rice, tomato, legumes, cassava, and pumpkin (Schaefer and Panizzi, 2000). Furthermore, some species in this family have been described as vectors of disease in some plants, and can transmit, by penetration of the stylets, microorganisms such as fungi, bacteria, and viruses (Boher et al., 1983).

This family includes species of bright colors and large sizes, which highlights that the genus Pachylis is the main representative of Coreoidea in Brazil, and insects are $35 \mathrm{~mm}$ in length (Lima, 1940). This family has a X0/XX sex chromosome system for males and females, a pair of $\mathrm{m}$-chromosomes, and a diploid chromosome number ranging from $2 \mathrm{n}=13(10 \mathrm{~A}+2 \mathrm{~m}$ $+\mathrm{X} 0)$ to $2 \mathrm{n}=27(24 \mathrm{~A}+2 \mathrm{~m}+\mathrm{X} 0)$, with $2 \mathrm{n}=21(18 \mathrm{~A}+2 \mathrm{~m}+\mathrm{X} 0)$ being the most common (Bressa et al., 2008).

In Heteroptera, although the division of sex chromosomes is well defined as postreductional for most of its representatives, i.e., the first meiotic division is equational and the second reductional to the sex chromosomes, it has been found that some species undergo pre-reduction division. That is, the first meiotic division is reductional and the second is equational for the sex chromosomes. These species include Archimerus alternatus (Coreidae), Anisops fieberi (Notonectidae), Ectrychotes disparate (Reduviidae), and Dictyonota tricornis 
(Tingidae), as well as some species of the genus Pachylis (Ueshima, 1979; Papeschi et al., 2003). Thus, this study aimed to characterize the meiotic behavior of $P$. laticornis, in order to consider whether this species also features pre-reduction division for the sex chromosomes.

\section{MATERIAL AND METHODS}

Three P. laticornis adult males were collected from São José do Rio Preto, São Paulo, Brazil (20'46'48.2"S, 49 21'18.3"W) and taken to the Laboratory of Cytogenetics and Molecular of Insects, where they were fixed in a 3:1 methanol/acetic acid solution. Subsequently, the testicles were removed and placed in saline, according to Demerec and Kaufmann (1945). Slides were prepared using the testicles obtained, and were stained with lacto-acetic orcein (De Vaio et al., 1985). Images were acquired using light microscopy under a ZEISS AXIO SCOPE A1 with AXION VISION LE 4.8 software for image analysis. The images were magnified by a factor of $1000 \mathrm{X}$.

\section{RESULTS}

Cytogenetic analysis of P. laticornis meiosis made it possible to determine that during prophase I, the X sex chromosome is heteropycnotic (Figure 1a), and is represented by a single corpuscle. In diplotene/diakinesis, (Figure 1b), beyond the presence of the $\mathrm{X}$ sex chromosome and the m-chromosomes, it was also possible to observe the presence of chiasmus between the autosomes, the absence of pairing, and concomitantly, of chiasmus between the m-chromosomes. The cells in metaphase I were observed in both lateral (Figure $1 \mathrm{c}, \mathrm{d})$ and polar view (Figure 1e), which made it possible to characterize the holocentric nature of the chromosomes and the karyotype of the species: $2 \mathrm{n}=15(2 \mathrm{~m}+12 \mathrm{~A}+\mathrm{X} 0)$. Note that all autosomes and the m-chromosome were bivalent and the $\mathrm{X}$ sex chromosome was pseudobivalent. By analyzing the final stage of anaphase I (Figure 1f), the X sex chromosome was observed to migrate late to one of the cellular poles with both sister chromatids characterizing pre-reductional meiotic division.

Analysis of telophase I revealed one cell with, and on cell without a sex chromosome (Figure 1g), which characterizes the pre-reductional meiotic division of the $\mathrm{X}$ sex chromosome. During telophase II, the absence (Figure $1 \mathrm{~h}$ ) or presence (Figure 1i, j) of the $\mathrm{X}$ sex chromosome can be viewed in both cells. The pre-reductional behavior of the $\mathrm{X}$ sex chromosome after meiosis results in the development of spermatids with $\mathrm{X}$ sex chromosomes, and chromosomes without sexual spermatids, as represented by the scheme in Figure 2.

\section{DISCUSSION}

The description of heteropteran meiosis has contributed substantially to the taxonomic and evolutionary knowledge of these species (Ueshima, 1966; Ueshima, 1979). All species of the order Hemiptera have holocentric chromosomes (Ueshima, 1979), as observed for $P$.

laticornis. These chromosomes are characterized by the absence of a centromeric region, since the kinetochore is diffuse throughout the chromosome (Ueshima, 1966; Ueshima, 1979).

Besides the holocentric nature of chromosomes, the meiotic metaphase allowed the chromosomal number of $P$. laticornis to be classified as $2 \mathrm{n}=15(12 \mathrm{~A}+2 \mathrm{~m}+\mathrm{X} 0)$. This karyotype followed the pattern described for species of the family Coreidae (a pair of 


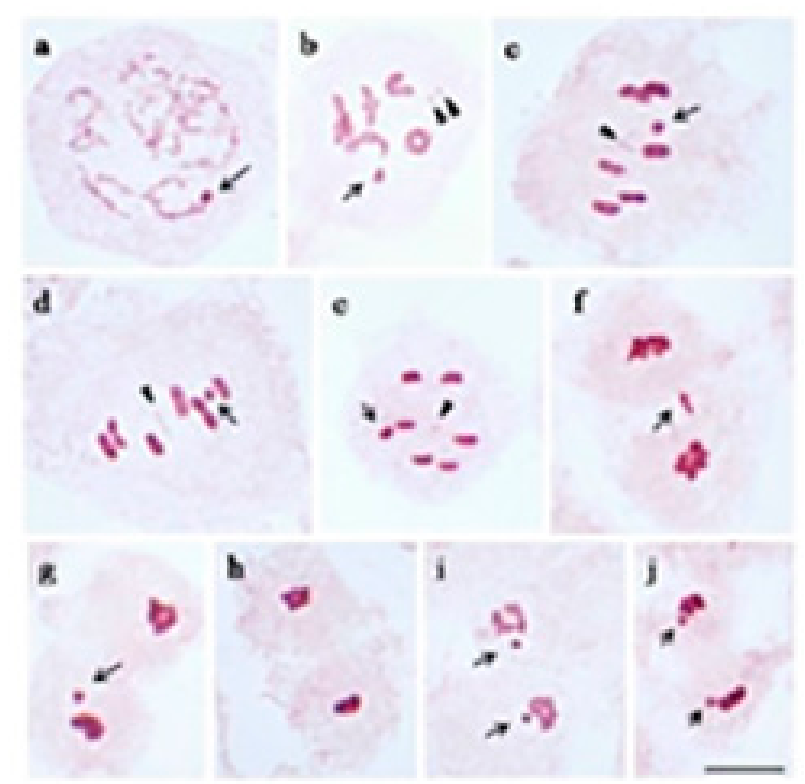

Figure 1. Pachylis laticornis meiosis. a. Prophase I, with heteropycnotic sex chromosome; b. diplotene/diakinesis, showing the presence of the m-chromosomes and the sex chromosome; c. d. metaphase I in side view, showing the m-chromosomes, the sex chromosome, and autosomes with telomeric association; e. polar view, showing the $\mathrm{X}$ chromosome and $\mathrm{m}$-chromosomes in the center of the autosomes ring; $\mathbf{f}$. end of anaphase I, showing the $\mathrm{X}$ chromosome with late migration; g. telophase I, showing the sex chromosome X; h. telophase II, with the absence of a sex chromosome; i. j. telophase II, demonstrating the presence of the sex chromosome in both cells. Arrow $=$ $\mathrm{X}$ chromosome; arrowhead $=\mathrm{m}$-chromosomes. Bar $=10 \mathrm{~mm}$.

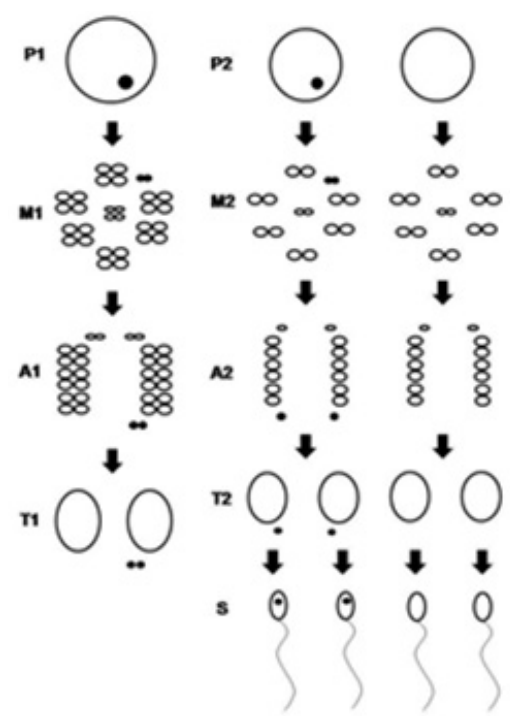

Figure 2. Scheme showing the formation of spermatids with the presence and the absence of the $\mathrm{X}$ sex chromosome. P1) Prophase I; M1) metaphase I; A1) anaphase I; T1) telophase I; P2) prophase II; M2) metaphase II; A2) anaphase II, T2) telophase II, S) spermatids. 
m-chromosomes and sex chromosomal system of the type X0) (Ueshima, 1979; Grozeva and Nokkala, 1996; Bressa et al., 2008).

The m-chromosomes of P. laticornis followed the default behavior described during meiosis, because they presented themselves as monovalent during prophase and bivalent during metaphase. Owing to this behavior, it is suggested that the m-chromosomes do not perform genetic recombination during pachytene (Ueshima, 1979). Ueshima (1979) suggests that the m-chromosomes are present in the first meiotic reduction division and equational division in the second division, following the meiotic behavior observed for the autosomes, as was observed in P. laticornis.

P. laticornis showed pre-reduction division for the $\mathrm{X}$ chromosome and the autosomes. This type of division, although common for organisms with monocentric chromosomes (Ueshima, 1979), is relatively uncommon for heteropterans, which usually present the first meiotic division as equational for the sex chromosomes (Ueshima, 1979), as showed by Ueshima (1979), Papeschi et al. (2003), Bressa et al. (2005), Souza (2009), Souza et al. (2007a,b, 2011), and Castanhole et al.(2008; 2010; 2012). However, pre-reduction division was also reported for species of the genus Pachylis ( $P$. aff pharaonis, P. argentinus, $P$. lateralis), Archimerus (A. alternatus e A. calcarator) (Coreidae), the genus Anisops (A. fieberi, A. niveae, and A. sardea) (Notonectidae), Ectrychote dispar (Reduviidae), as well as for all species of the family Tingidae, prior to cytogenetic study (Ueshima, 1979; Papeschi et al, 2003, Ramos, 2009).

During anaphase and telophase I, the $\mathrm{X}$ chromosome underwent late migration. This phenomenon is relatively common in the suborder Heteroptera (Mendonça, 2010; Succi et al., 2014; Vicente Pereira, 2015; Pereira et al., 2015), and according to Morielle and AzeredoOliveira (2004), it is associated with the equational division of the sex chromosomes. However, P. laticornis presented pre-reductional meiotic behavior of the sex chromosome in the first division, thus excluding the possibility of this phenomenon being associated with the equational division of the sex chromosomes.

At the end of the second meiotic division, specifically in telophase II, P. laticornis presented the absence or presence of the X sex chromosome in both cells, confirming prereductional meiosis of the $\mathrm{X}$ chromosome in that species.

The findings of the present study describe the number of chromosomes, the system of sex determination, and the meiotic behavior of P. laticornis, corroborating the relationship of this species with others of the same genus. Furthermore, with this analysis, we can confirm the presence of pre-reductional meiotic behavior for another species of the Heteroptera, stressing the importance of cytogenetic studies for increasing our understanding of variation in spermatogenesis of heteropterans.

\section{ACKNOWLEDGMENTS}

We are grateful to Prof. Dr. Luis Alves Costa for the identification of the studied species and the development agencies FAPERP, FAPESP, CNPq, and CAPES for providing financial support.

\section{REFERENCES}

Boher B, Daniel JF, Fabres G and Bani G (1983). Action de Pseudo theraptus devastans (Distant) (Het., Coreidae), et de Colltotrichum gloeosporioides Penz. Dansle développement de chancres et la chute desfeuilles chez lemanioc (ManihotesculentaCrantz). Agronomie 3: 989-993. 
Bressa MJ, Larramendy ML and Papeschi AG (2005). Heterochromatin characterization in five species of Heteroptera. Genetica 124: 307-317. http://dx.doi.org/10.1007/s10709-005-4524-3

Bressa MJ, Franco MJ, Toscani MA and Papeschi AG (2008). Heterocromatin heteromorphism in Holhymenia rubinosa (Heteroptera: Coreidae). Eur. J. Entomol. 105: 65-72. http://dx.doi.org/10.14411/eje.2008.009

Castanhole MMU, Pereira LLV, Souza HV, Bicudo HE, et al. (2008). Heteropicnotic chromatin and nucleolar activity in meiosis and spermiogenesis of Limnogonus aduncus (Heteroptera, Gerridae): a stained nucleolar organizing region that can serve as a model for studying chromosome behavior. Genet. Mol. Res. 7: 1398-1407. http://dx.doi. org/10.4238/vol7-4gmr527

Castanhole MMU, Pereira LLV, de Souza HV, Valério JR, et al. (2010). Meiotic chromosomes and nucleolar behavior in testicular cells of the grassland spittlebugs Deois flavopicta, Mahanarva fimbriolata and Notozulia entreriana (Hemiptera, Auchenorrhyncha). Genet. Mol. Biol.33:244-252.http://dx.doi.org/10.1590/S1415-47572010005000025

Castanhole MMU, Pereira LLV, de Souza HV and Itoyama MM (2012). Spermatogenesis of riffle bugs, Rhagovelia whitei and Rhagovelia sp (Veliidae), and backswimmers Martarega sp (Notonectidae). Genet. Mol. Res. 11: 2003-2020. http://dx.doi.org/10.4238/2012.August.6.5

De Vaio ES, Grucci B, Castagnino AM, Franca ME, et al. (1985). Meiotic differences between three triatomine species (Hemiptera: Reduviidae). Genetica 67: 185-191. http://dx.doi.org/10.1007/BF02424489

Demerec M and Kaufmann BP (1945). Drosophila Guide. The Lord Baltimore Press, Baltimore.

Grozeva S and Nokkala S (1996). Chromosomes and their meiotic behaviour in two families of the primitive infraorder Dipsocoromorpha (Heteroptera). Hereditas 125: 31-36. http://dx.doi.org/10.1111/j.1601-5223.1996.t01-1-00031.x

Lima C (1940). Insetos do Brasil. $2^{\circ}$ tomo, Hemípteros. Escola Nacional de Agronomia. Série didática no 3, cap. XXII, p. 352.

Mendonça PP (2010). Estudo Comparativo das Caracteríscitcas Citogenéticas e Moleculares de Triatoma maculata e Triatoma pseudomaculata (Triatoma, Heteroptera). Master's thesis. Universidade Estadual Paulista, São José do Rio Preto.

Morielle A and Azeredo-Oliveira MTV (2004). Description of the nucleolar activity and Karyotype in germinative cell lines of Rhodnius domesticus (Triatominae, Heteroptera). Caryologia 57: 31-37. http://dx.doi.org/10.1080/0008711 4.2004.10589369

Papeschi AG, Mola LM, Bressa MJ, Greizerstein EJ, et al. (2003). Behaviour of ring bivalents in holokinetic systems: alternative sites of spindle attachment in Pachylis argentinus and Nezara viridula (Heteroptera). Chromosome Res. 11: 725-733. http://dx.doi.org/10.1023/B:CHRO.0000005740.56221.03

Pereira LLV, Alevi KCC, Moreira FFF, Barbosa JF, et al. (2015). Study of nucleolar behavior during spermatogenesis in Martarega brasiliensis (Heteroptera, Notonectidae). Genet. Mol. Res. 14: 8988-8994. http://dx.doi.org/10.4238/2015. August.7.7

Ramos ICG (2009). Caracterização citogenética de Leptoglossus gonagra e Pachylis aff pharaonis (Heteroptera, Coreidae). Dissertação. Universidade Federal de Pernambuco.

Schaefer CW and Panizzi AR (2000). Heteroptera of economic importance: a general view. CRC Press LLC, pp. 1-8.

Schuh RT and Slater JA (1995). True Bugs of the World (Hemiptera; Heteroptera: Classification and Natural History). Ithaca, London: Cornell University Press.

Souza HV (2009). Espermatogênese e comportamento nucleolar em espécies da família Pentatomidae (Heteroptera) de importância econômica. Dissertação. Universidade Estadual Paulista.

Souza HV, Arakaki RLM, Dias LN, Murakami AS, et al. (2007a). Cytogenetical Aspects of Testicular Cells in Economically Important Species of Coreidae Family (Heteropera). Cytologia (Tokyo) 72: 49-56. http://dx.doi. org/10.1508/cytologia.72.49

Souza HV, Campos Bicudo HEM, Costa LAA and Itoyama MM (2007b). A study of meiosis an spermiogenesis in the testicular lobes of Antiteuchus tripterus (Heteroptera: Pentatomidae). Eur. J. Entomol. 104: 353-362. http://dx.doi. org/10.14411/eje.2007.053

Souza HV, Murakami AS, Moura J, Almeida EC, et al. (2011). Comparative analysis of the testes and spermatogenesis in species of the family Pentatomidae (Heteroptera). Eur. J. Entomol. 108: 333-345. http://dx.doi.org/10.14411/ eje.2011.041

Succi M, Alevi KCC, Mendonça PP, Bardella VB, et al. (2014). Spermatogenesis in Triatoma williami Galvão. Souza and Lima (1965) (Hemiptera, Triatominae). Invertebr. Reprod. Dev. 58: 124-127. http://dx.doi.org/10.1080/079242 $\underline{59.2013 .855268}$

Ueshima N (1966). Cytotaxonomy of the Triatominae (Reduviidae: Hemiptera). Chromosoma 18: 97-122. http://dx.doi. org/10.1007/BF00326447

Ueshima N (1979). Animal cytogenetics, Insecta, Hemiptera: Heteroptera. Gebruder Borntraeger: Berlin, Stuttgart.

Genetics and Molecular Research 15 (2): gmr.15027592

CFUNPEC-RP www.funpecrp.com.br 
Vicente Pereira LL, Chaboli Alevi KC, Urbanin Castanhole MM, Figueiredo Moreira FF, et al. (2015). Cytogenetics Analysis and Testis Morphology of Aquatic Species of the Families Belostomatidae, Gelastocoridae, Gerridae, Notonectidae, and Veliidae (Heteroptera). J. Insect Sci. 15: 1-10.

Weirauch C and Schuh RT (2011). Systematics and evolution of Heteroptera: 25 years of progress. Annu. Rev. Entomol. 56: 487-510. http://dx.doi.org/10.1146/annurev-ento-120709-144833 